\title{
Environmental reconstruction of the Saronikos Upper Pleistocene Paleolake, Central Greece; preliminary results
}

\author{
NEFELI KAFOUSIA ${ }^{1}$, ELENI KABERI ${ }^{1}$, GRIGORIS \\ ROUSAKIS $^{1}$, MARIA MARIA TRIANTAPHYLLOU ${ }^{2}$, \\ VASILEIOS MAVROMATIS ${ }^{3}$, ELENI KOUTSOPOULOU ${ }^{4}$, \\ ALEKA GOGOU $^{1}$ AND ARISTOMENIS KARAGEORGIS ${ }^{1}$ \\ ${ }^{1}$ Hellenic Centre for Marine Research \\ ${ }^{2}$ National and Kapodistrian University of Athens \\ ${ }^{3}$ Géosciences Environnement Toulouse (GET)-CNRS \\ ${ }^{4}$ Institute of Geological and Mineral Exploration (IGME) \\ Presenting Author: n.kafousia@hcmr.gr
}

Glacial-interglacial cycles triggered significant paleoenvironmental perturbations that were recorded as sea-level fluctuations over the past millennia. The sea level fluctuations, in areas with complex coastline as the Eastern Mediterranean, and particularly Greece, had as a result the isolation of semi-enclosed Gulfs and the formation of paleolakes. In previous studies at such paleolakes, a noteworthy carbonate sequence with the main presence of aragonite was recorded [1,2].

During the last glacial lowstand (sea level at $-125 \mathrm{~m}$ ), the western sector of the Saronikos Gulf was disconnected from the open Aegean Sea, thus forming a paleolake. In the present work, we present preliminary results from two sediment cores recovered from the western Saronikos Gulf. Both cores present a sedimentary interplay between marine-lake-marine conditions. From bottom to top, we observe typical marine sediments, followed by a thick carbonate sequence, composed mainly of aragonite, and then again by marine sediments. This study focuses on the environmental reconstruction of the period during which the western Saronikos was isolated. At first, a detailed chronology of the sedimentary deposits is attempted using ${ }^{14} \mathrm{C}$ and U/Th datings. Subsequently, we aim to identify the smallscale paleoenvironmental events that have been recorded during the paleolake period, where carbonate sedimentation prevailed. Trace and major elements analysis conducted at high-resolution revealed several discrete events characterized by peaks of $\mathrm{Ti} / \mathrm{Al}$, $\mathrm{S} / \mathrm{Al}, \mathrm{Ba} / \mathrm{Al}, \mathrm{V} / \mathrm{Al}, \mathrm{Mo} / \mathrm{Al}$, and $\mathrm{Fe} / \mathrm{Mn}$ ratios which indicate variable fluxes of freshwater and terrigenous material, as well as varying redox conditions. These results provide geochemical information on small-scale environmental and climatic events that occurred during the last glacial period and deglaciation.

References

[1] Richter, Anagnostou \& Lykousis (1993) Bulletin of the Geological Society of Greece 28, 553-562.

[2] Karageorgis, Kanellopoulos, Mavromatis, Anagnostou, Koutsopoulou, Schmidt, Pavlopoulos, Tripsanas \& Hallberg (2013). Geo-Marine Letters, 33(1), 13-29. 